\title{
"I Face a Dark Future": Patient Letters from the Leprosy Archives, Bergen
}

\author{
Marie-Theres Federhofer
}

University of Troms $\varnothing$ - The Arctic University of Norway

\section{ABSTRACT IN ENGLISH}

This article focuses on letters sent by leprosy patients or their family members applying for place at a leprosy hospital. Written between 1871 and 1911, the letters now form part of the Leprosy Archives in Bergen, and have not been presented, contextualized and analysed before. The article aims to illuminate both the sufferers' experiences of leprosy and the ways in which they recount those experiences in their letters. The concept of "small stories" (Michael Bamberg and Alexandra Georgakopoulou) serves as an entry point to access the narrative techniques in these autobiographical and biographical documents.

\section{OPPSUMMERING PÅ NORSK}

Denne artikkelen ser på brev som ble skrevet av spedalske eller deres pårørende da de søkte om opptak på en institusjon for spedalske. Brevene ble skrevet mellom 1871 og 1911 og oppbevares i dag på Lepraarkivene i Bergen. For første gang presenteres og analyseres disse dokumentene i en større sammenheng. Formålet med denne artikkelen er å presentere sykdomserfaringer til de spedalske samt måten disse erfaringene er blitt fremstilt på. «Small stories»-konseptet (Michael Bamberg/Alexandra Georgakopoulou) brukes som utgangspunkt for å analysere de narrative teknikkene i disse selvbiografiske og biografiske tekstene.

\section{KURZFASSUNG IN DEUTSCH}

Der Artikel befasst sich mit Patientenbriefen, die von Leprakranken oder deren Angehörigen verfasst wurden und mit denen sie um Aufnahme in einem 
Leprahospital baten. Die Briefe wurden zwischen 1871 und 1911 geschrieben und befinden sich heute im Lepraarchiv in Bergen. Diese Dokumente werden hier erstmals im Zusammenhang präsentiert und analysiert. Ziel des Artikels ist es, die Krankheitserfahrungen von Leprakranken sowie die Art und Weise, wie sie diese Erfahrungen darstellen, offenzulegen. Das "small-stories"-Konzept (Michael Bamberg/Alexandra Georgakopoulou) dient als Ausgangspunkt, um die narrativen Techniken in diesen autobiographischen bzw. biographischen Dokumenten zu analysieren.

Keywords: patient letters; leprosy; leprosy policies in Norway, nineteenth century; narrative theory; small stories

\section{PATIENT LETTERS AND NARRATIVE THEORY}

The scope of narratology-oriented literary scholarship has experienced a surprising expansion in recent times. This is due to the insight of the "narrative turn" (Kreiswirth 1995, 2005) that acts of narration are far from being limited to fiction alone. Narrative happens in many other domains-in the sciences and humanities, in economics, in politics, in schools, in the legal system, and so on. The ubiquity of narrative arises from the capacity of stories to structure and mediate knowledge. Albrecht Koschorke encapsulates the point as follows: "this successful expansion [of the notion of narrative] is founded on the realization that narrative is an essential element in the organization of orders of knowledge" (Koschorke 2013, 329). From this perspective, narrative has an epistemological function; it is a knowledge-generating, meaning-giving activity that itself exerts influence on social practices.

The actual analysis of narratives tends to be left to the discipline that possesses a sophisticated toolbox of narratological concepts and therefore seems to be genuinely best qualified for the task: the discipline of literary studies. But this raises a problem. Those areas of literary studies that are interested in narrative theory have so far paid comparatively little attention to non-literary texts; they have honed their narratological methodologies mainly by engaging with literary texts (Genette 1990, 755-756; Kreiswirth 2005, 380-381; Koschorke 2013, 329). If I, as a literary scholar, examine the "real" stories - that is, not fictional ones-in which nineteenth-century Norwegian leprosy patients or their relatives narrate their experiences of illness in letters, I thus find myself on rather uncharted territory. Hitherto, neither the historiography of medical patients in general nor patients' letters as a genre of historical documents have attracted any substantial attention from literary scholarship. ${ }^{1}$ One exception is the 
pioneering work of the Norwegian literary scholar Petter Aaslestad in The Patient as Text (Aaslestad 2009 [1997]). Examining the narratological configurations of around 150 patient files from a Norwegian psychiatric hospital, written between 1890 and 1990, Aaslestad uses the narratological categories of voice and mood to analyse who is speaking in these reports, which perspectives are reproduced in them, and in what ways. The history of patients has increasingly come to the fore in recent years, but, as I have said, such interest has been much less evident in literary studies than in sociology, the history of science, and cultural history (Porter 1985; Duden 1991; Loetz 1993; Lachmund and Stollberg 1995; Wolff 1998; Ernst 1999, 2003; Stolberg 2001, 2003; Rieder 2003; Osten 2010). We find a similarly uneven picture when it comes to the disciplinary distribution of interest in testimonies that represent experiences of illness from the viewpoint of patients themselves. Of course, sources of this kind-such as diaries or letters-are normally difficult to find. They are often unpublished and for the most part are held in archives or private collections. ${ }^{2}$ And the few studies so far based on patient letters are, once again, to be found not in the field of literary scholarship but in cultural studies or the history of medicine (Stolberg 1996, 2003; Ritzmann 2001). Work in these disciplines is inevitably less interested in asking how narration takes place in such letters, and more in using the letters as documents capable of exemplifying or explaining historical processes.

My attempt to approach letters from nineteenth-century leprosy patients narratologically is not made any easier by the fact that the letters do not tell complex stories. In Gérard Genette's terms, they are "minimal forms of narrative", "minimal narrative[s]" (Genette 1980, 30; Genette $1988,18)$. To put the point rather crudely: these narratives offer little that is particularly startling, little that could be pored over through the narratological microscope or dissected with a carefully crafted terminology. Nevertheless, even these miniature narratives follow recurrent narrative patterns. In this paper, I will test out a related concept that has recently been developed in sociolinguistics, the notion of "small stories". Expanding that perspective, I argue that a narratological description of non-fiction prose texts is only really useful if it simultaneously takes account of the cultural context to which those texts belong. This assertion is based on the conjecture that the act of narration influences the cultural environment within which that act takes place. My approach is underpinned by two recent publications in literary studies which-while very different in their approach and implementation-share the conviction that narrative always happens within particular cultural fields, and that any narrative theory has to be anchored in a theory of culture. These are a collection of essays edited by Christian Klein and Matías Martínez 
in 2009, Wirklichkeitserzählungen: Felder, Formen und Funktionen nichtliterarischen Erzählens (Reality Narratives: Fields, Forms and Functions of Non-Literary Narration) and Albrecht Koschorke's 2012 monograph Wahrheit und Erfindung: Grundzüge einer Allgemeinen Erzähltheorie (Truth and Invention: Principles of a General Theory of Narrative). Klein and Martínez introduce the concept of "reality narratives" into narratological terminology, referring to spoken or written stories that claim to be "directly anchored in a reality external to language" (Klein and Martínez 2009, 6). Koschorke takes the point further, postulating that "a narrative theory $[\ldots]$ cannot be had without a corresponding cultural theory" (Koschorke 2013, 22). But before I turn to the aspect of the "small story" and its cultural contextualization, I will briefly present my sources-an outline that itself is a form of contextualization.

\section{LETTERS FROM THE LEPROSY ARCHIVES IN BERGEN}

Dear Chief Medical Officer Löberg,

With the deepest respect I take the liberty of asking you to admit me to the Pleiestiftelsen Leprosy Hospital. The reason I left the hospital was that my wife was bedridden for several years and when I left the landowner tried to drive her out into the open countryside, even though I leased our land for the whole of her lifetime and my own lifetime. When my wife wrote to tell me, I hadn't the heart not to go back home to her, so I was forced to leave the hospital to straighten out her situation. Now in the meantime my wife has died, and because I am unfortunate enough to suffer from an illness with no hope of cure, indeed quite the opposite I find myself getting weaker day by day, I have no one here to turn to for help, and without your kindness I face a dark future. This is why I repeat most humbly my request to be readmitted to the hospital. ${ }^{3}$

This poignant letter was sent by the smallholder Knud Larsen Hjelmeland two days before Christmas, on 22 December 1871, to the physician Timandus Jonas Løberg. Løberg held the post of chief medical officer, a senior official appointment instituted by the Norwegian Parliament in 1854. The chief medical officer in Løberg's time bore the highest medical responsibility for care and treatment of leprosy patients across Norway. His tasks included directing the four state leprosy hospitals, one of which was "Pleiestiftelsen No. 1" in Bergen, mentioned in the letter. ${ }^{4}$ The four institutions were established in the period between 1849 and 1861. Both the creation of a national chief medical officer position and the establishment of dedicated institutions for leprosy patients formed part of a state-controlled 
health policy by means of which nineteenth-century Norway hoped to conquer the disease. At the time, leprosy was a serious problem that affected especially the poorer population, particularly in the coastal regions of western Norway. In 1856, Norway had around 3000 people suffering from leprosy. By the early twentieth century, that number had dropped to 577, and the last leprosy patient in Norway died in the 1970s (Vollset 2013, 9). When Pleiestiftelsen No. 1 opened its doors in summer 1857, there were already 295 applications for admission awaiting a decision-suggesting that the facility was responding to a genuine need from the population. ${ }^{5}$ Today, we know not much about the fate of the unfortunate Knud Larsen Hjelmeland. We know that his request to be admitted to the hospital in Bergen was granted, that he was admitted on 4 March 1872 and that he died as a patient there on 16 February 1873.

This letter is one of around a dozen that I found in the Leprosy Archives in Bergen, sent by leprosy patients or their family members. They were written between 1871 and 1911. ${ }^{6}$ The letter from Larsen Hjelmeland is one of the documentary traces left by state-controlled intervention in the field of leprosy treatment in nineteenth- and early twentieth-century Norway. Certainly, these patient letters-this is the term I will use for simplicity's sake, even though they were written before the leprosy sufferers became "patients", and in some cases not by the patients themselves but by family members-are marginal traces. They are marginal not only because there are so few of them, but also because of the very modest role they have played in research, especially in comparison to the patient notes, annual reports and statistics written by the doctors treating leprosy. ${ }^{7}$ These two dimensions of marginality are, of course, connected: the small number of the patient letters that have, probably more by accident than design, survived in the Leprosy Archives makes them less attractive for researchers. As far as I am aware, they have almost never been used as sources for scholarship. ${ }^{8}$ The notes, files and protocols produced by the doctors form a far more extensive and also more high-profile corpus of source material, which has been favoured by the research literature. The status of these documents can be inferred from the fact that some of them have been digitized and made available online. The Bergen Leprosy Archives, where this material is held today, have been a UNESCO World Heritage site since $2001 .^{9}$

The leprosy-related material has not survived by chance. It was preserved in the Bergen Leprosy Archives as a result of the institutionalization and state funding of leprosy treatment in the nineteenth century-because the process of institutionalization entailed an obligation to deliver regular reports, create standardized documentation, and collect systematic data. Evidently, doctors and politicians alike believed 
that medical progress depended in part on a well-organized research infrastructure, enabling research data to be systematically gathered and made accessible to a larger scientific community. The idea of promoting targeted research and research networking in order to overcome the disease proved to be well-founded: scientists in Norway succeeded in identifying the leprosy bacterium and thus showing that leprosy is not a hereditary disease but ultimately a communicable one. The discovery of Mycobacterium leprae by the Norwegian doctor Gerhard Armauer Hansen in 1873 brought about a paradigm change in leprosy research. Additional innovations came in the domain of administration. In connection with the state's surveillance of leprosy, the world's first disease statistics were collated, giving an overview of the age, gender, geographical origins and marital status of leprosy patients. Starting in 1856, everyone with leprosy in Norway was recorded statistically, and the resulting register formed the basis of the later national registers of health. One might say that a surge of modernization in aetiology and epidemiology emanated from Norway that was admired by other European nations and, perhaps ironically, driven by a most "un-modern" disease, a symptom of social backwardness-for leprosy had become extremely rare in Europe by the nineteenth century. ${ }^{10}$

\section{MARGINAL TRACES}

Let me return now to the documents that were generated by the state's efforts to control the disease and that, in their turn, were subjected to a controlled logic of storage and archiving. The patient notes, registers and statistics are, as I have said, the prime sources and documentation upon which the research literature tends to rely when approaching leprosy from the perspective of the history of medicine, the history of institutions, social history, or cultural history. These historiographical reconstructions often follow a narrative of success. In one sense, that is hardly surprising, given the historical highlights I have mentioned-the world's first national disease statistics, the identification of the bacterium, and finally the successful campaign to combat the disease.

Yet what about marginal documents like the letter from Larsen Hjelmeland? They are "witnesses in spite of themselves" ("témoins malgré eux"), as Marc Bloch once called documents that were not intended to be preserved for posterity (Bloch 1953, 51).

Clearly, the story these testimonies tell is-from their individual perspective-not a story of success, but a story of decline. My attention to the letters of "ordinary people", the letters of Knud Larsen Hjelmeland 
and Nikoline Benjaminsdatter, of Johannes Mikelsen Kolstad and Maria Jakobsdatter Eide, of Jakob Jakobsen and Tore Knutsen Bugge is not motivated by a wish to cast doubt on the national and collective narrative of success. These individual accounts of loss, poverty and isolation do not force us to rewrite the story of how leprosy was combated in Norway. So what knowledge do we stand to gain by listening to these witnesses? I would like to answer that question, very provisionally, by saying that attending to such marginal documents can illuminate the connections between narrative and social praxis. Put differently: the functioning of the state's control and surveillance of leprosy, in other words the functioning of political and social practices, owed its success in part to narrative practices.

The documents testify to contact initiated by future or former patients (or their relatives) with hospitals and doctors. They are letters written to apply for admission to the leprosy hospital. In just a few lines, sometimes using clumsy handwriting and awkward language, life stories are told. A widowed and penniless father tells of the death of his wife from leprosy and explains that his two sons, aged twenty and twenty-two, have also fallen ill with the disease; he asks for the older son, "Ole Monsen, who suffers severely from leprosy", ${ }^{11}$ to be admitted to the hospital in Bergen: "Because I am a man of modest circumstances in matters of wealth, I cannot give my sick son the care he needs and I hope I will be granted the help that I request."12 A mother, Else Jakobsen, writes "in great dejection"13 in the name of her sick son, who has become incapable of writing himself because of his illness; she asks for a place at the Pleiestiftelsen hospital: "Recently his eyes have got so bad and one of his hands is very weak. So $[\ldots]$ he is not able to make his own living. He can see so little that he cannot write to you himself." ${ }^{14}$ Relatives of a former patient ask for him to be readmitted to Pleiestiftelsen No. 1 because his health has deteriorated severely and it is not possible to house him separately from the rest of the family. Although the sick man, Johannes Johnsen Telle, previously left the institution without permission, his doctor or pastor "nonetheless take the liberty of recommending his admission to Pleiestiftelsen [No. 1] again, because [...] his condition seems to have become worse and because it must be feared that staying in the cramped accommodation of his home, where there are several children, would have worrying consequences both for him and for them." ${ }^{15}$ Poor country-dwellers, no longer able to work and with no more money to support themselves, ask for their own admission, for example in the case of Maria Jakobsdatter Eide, aged thirty-six: "I must beg you most respectfully if you could make it possible for me to receive a place and be admitted to the leprosy hospital in Bergen in the autumn. I am now getting so weak that it is very 
difficult to care for me here at home and so I thought of trying to travel to Bergen if I could get a place there."16

The request for admission written by Tore Knutsen Bugge, a man around seventy-five years of age, is something of an oddity. Bugge had already spent time in several different care institutions, but he always ran away. Now, however, he feels very ill at ease in his village environment and would like to be admitted to a hospital again. A handwritten annotation on this letter indicates that Bugge probably never had leprosy. Nevertheless, his admission was recommended, given that he was anyway very elderly and had already spent so many years of his life in leprosy hospitals: "It will hardly do any harm to grant his wish."

The letters may be assigned to the pragmatic genre "letters of application", and this formal context also affects the substance. The writers communicate only the bare necessities, rarely revealing their own feelings in the face of their desperate situation. One such rare case is Else Jakobsen, who makes the application on behalf of her son Jørgen. She writes: "Oh, how hard it is for a mother who, if I may say so, has to bear the sorrow alone and whose dearest one has been crushed a thousand times." ${ }^{18}$ The causative agent of leprosy having been discovered in 1873 and the contagious nature of the disease understood, in 1877 the Norwegian parliament passed a law requiring everyone with leprosy to be accommodated in a closed institution, in order to prevent further infections. ${ }^{19}$ This law does not appear to have been pursued with great rigour: we know that in the late 1880s, more people suffering from leprosy were living outside than inside the care institutions (Gussow 1989, 70, 79; Andresen 2004, 97). The letters I present here were written both before and after the law of 1877 , and it is not entirely clear what degree of voluntariness should be attributed to the sufferers writing to request admission to the institutions post-1877. At least in the case of some letters, for example the one from the Telle family quoted above, we can infer that parts of the local population were well aware of the danger of infection. A letter written in 1876 by the pastor Niels Anton Aall shows that parish-level poor relief also played an important role and that the new medical knowledge of leprosy's communicability had practical consequences for sufferers, impelling their admission to institutions. Pastor Aall wrote the letter at the request of the poor relief authorities of Naustdal, a district in western Norway, to the chief medical officer at Pleiestiftelsen No. 1: "Gunder Kristiansen Espeland [...] has applied to me and declared himself willing to travel. Because it is possible that later on he may no longer be willing to travel, and because, in consideration of your article in the Bergensposten of the 29th of this month, I must regard it as my [...] duty to ensure that leprosy sufferers are kept separate to the greatest possible degree, I hope that in 
view of the circumstances you will not object [...] to my now sending him off to you." 20

Certainly, these patient letters are unspectacular from a narratological perspective. Yet they describe the writer's situation from her or his own perspective and contain life histories en miniature. All these miniature narratives follow the schema "Person X falls ill; person X can no longer look after him- or herself or be looked after by friends and family; person X requests admission to the leprosy hospital." To follow Genette's definition of a minimal narrative, the stories tell of a transition-the sufferers' passage from health to sickness, and the associated passage from their own home to a faraway hospital..$^{21}$ The small yet significant insight here is that these minimal narratives organize temporality. They portray a before and an after. A relationship is established between the situations before and after the illness, and it is given dynamism in the process of representation-a classic narrative procedure.

\section{4. "SMALL STORIES"}

To be sure, if my only finding were this demonstration that narrative elements also structure day-to-day writing such as letters of application, that would be a rather trivial benefit. This is why, as I promised at the start of the paper, I would like to use the concept of "small stories" to indicate how narrative takes place in a cultural space and can only be understood in terms of that space. For in fact these stories do not simply reflect a social praxis; they also influence it. Put another way, these are everyday stories whose function lies not in world disruption, but in worldmaking.

When sociolinguists Alexandra Georgakopoulou and Michael Bamberg introduced the concept of "small stories" into the scholarly debate (Bamberg 2006; Georgakopoulou 2006; Bamberg and Georgakopoulou 2008), their aim was above all to develop an "antidote to the long-standing tradition of "big stories"" (Georgakopoulou 2007, 147). Importantly, that did not mean postulating a "strict dichotomy between big and small stories"; rather, the aim was to excavate the "pluralism, heterogeneity, and productive coexistence of narrative activities, big and small" (Georgakopoulou 2015, 256). The explicitly "eclectic" approach (ibid., 257), its sources including biographical studies and discourse analysis, aspires to add sharper detail to a definition of narrative that is considered prototypical, one in which a narrative consists of a sequence of events (ibid., 259). The object of its investigations are the small stories told in settings such as family conversations, job interviews, postings on Twitter and Facebook, or asylum applications (ibid., 257, 265). These "neglected" narratives also 
"happened to be literally small" (ibid., 256). Georgakopoulou criticizes existing narrative research for its lack of attention to context (Georgakopoulou 2007, 64), ${ }^{22}$ and insists that "all narrative meaning making" must be seen as contextualized (Georgakopoulou 2015, 257). What is therefore needed are "contextualized studies of narrative as a social practice" (Georgakopoulou 2007, 65). In her own contributions to the study of small stories-these include the analysis of conversations in a group of adolescents, or of a corpus of emails exchanged between friendsGeorgakopoulou demonstrates that such stories are always discursively embedded, and always impact upon the social environment. From this work, she derives two general characteristics of small stories: they are typified by "immediacy", that is, the stories narrate "near future events (projections), very recent or still unfolding events"; and they establish "links between the participants' previous and future interactions" (Georgakopoulou 2007, 148). In other words, small stories are typified by a specific temporal structure inasmuch as the focus of narrative attention is not, as in the classic narratological approach, on past events, but on what is about to happen-Georgakopoulou refers to a "lack of temporal distance between the tale and the telling" (Georgakopoulou 2015, 267). Also typical is their influence on, or interaction with, the social praxis within which they are told. Small stories research therefore emphasizes that the telling of these everyday stories must be regarded as a speech act in a particular context; the narration performs "specific actions in specific environment" and is part of social practices, "shaping and being shaped by them" (Georgakopoulou 2015, 257).

Even in this very brief sketch, the "small stories" concept, which explicitly presents itself as a "model for, not a model of" narrative analysis (ibid., 256), appears to be productive for interpreting the narratives found in the letters of people with leprosy, for these stories, too, are the stories of "silenced, neglected, and marginalized voices" (ibid.). In their request for admission, the sick or their relatives recount only what is absolutely necessary about past events, instead relating their narratives to the current situation and the immediate future. That future may be the impending journey, as in the case of Nikoline Benjaminsdatter and her "decision to travel by Route 1 Wednesday morning the 23rd of this month", ${ }^{23}$ or the prospect of being allocated a particular room, as requested by the same applicant in an earlier letter: "I take the liberty, and ask the Director most kindly if he would be obliging enough to arrange for me to be given Room No. 17". ${ }^{24}$ The narrative may also, however, refer more generally to the future situation-a situation whose hopelessness and desolation is frankly admitted: "I face [...] a dark future." ${ }^{25}$ From the perspective of small stories research, this crucial aspect, common to all the letters I 
present here, could be described as the "proximity between the story and its actual telling" (Georgakopoulou 2015, 267).

The narratives on illness, destitution and helplessness have the concrete result of changing the protagonists' life situations. Their application for a place at the leprosy hospital is usually accepted, so they will have to leave their familiar environment and find their feet in new surroundings. But the letters of the leprosy patients also have a direct impact on other domains of everyday praxis: the required clothing for the hospitals has to be found and paid for, the poor relief authorities have to be mobilized in order to bear some of the costs, the arrival and departure of the patient has to be organized. Thus, the leprosy sufferer Johannes Mikelsen Kolstad appeals to his doctor to help him "get myself the necessary things that I will have to have with me", ${ }^{26}$ while the director of poor relief in Førde, western Norway, writes to the chief medical officer Hans Peter Lie that "it has been impossible for me to obtain complete outer garments for Ludvig and Johannes Gjesdal [...]. Please could you therefore purchase clothing for them in Bergen and charge it to Jølster." ${ }^{27}$ Another doctor is able to assure his patient, Nils Endresen Svien, that "you will be admitted there [Pleiestiftelsen No. 1] at any time. You will receive everything free, so only the journey will cost you anything". ${ }^{28}$

The fact that narratives are also a form of "social negotiation" (Koschorke 2013, 350) can be seen in the letters from people who have left leprosy hospitals without permission. They admit their infraction and repentantly ask for readmission, which in most cases is granted. The admission form for the deaf-mute Marta Kristine Kirstensen Brændvik, fifty-eight years old, carries the written annotation: "The patient has run away from the hospital twice, and is only admitted on condition that this is not repeated." ${ }^{29}$ On the one hand, the small stories of the leprosy patients are determined by their situation and owe their existence to a particular social context: the patients being unable to take care of themselves, and as a result applying for admission to a care institution. At the same time, however, social praxis and the social context are themselves shaped by the stories that are told and the ways that they are told. These stories are worth telling-“tellable", in William Labov's sense (Labov 1972, 370)— not because they recount a singular and striking event, but because they are intended to change the teller's own everyday life.

As I remarked at the beginning of this paper, these letters from leprosy patients will not change the historiography of Norway's battle against leprosy in the nineteenth century. But that was not the objective of my study. Instead, I wished to expand the spectrum of narratological perspectives and focus attention on everyday narratives, those terse and unpretentious stories of the lives and illnesses of "ordinary people", in order to explore 
the functions of narration in a particular historical and cultural context. Taking the concept of small stories from the linguistics of conversation, I have repurposed it, so to speak, by applying it to stories found in the fixed, written medium of the letter. The concept seems well suited to revealing facets of the patient stories that would have emerged less clearly from other points of view. Those facets include not only the temporal proximity between the telling and what is told, but also the embedment of narration in an everyday context and indeed the function of narrating itself.

\section{ACKNOWLEDGEMENTS}

I thank Grete Eilerten, the Bymuseet i Bergen, and Gina Dahl, Per Stian Kjendal and their colleagues at the Statsarkivet i Bergen for their help in researching this contribution. Translated by Kate Sturge.

\section{ARCHIVE MATERIAL-LIST OVER LETTERS}

22 December 1871, letter by Knud Larsen Hjelmeland

29 February 1884, letter by Johanes Mikelsen Kolstad

23 October 1886, letter by Jakob Jakobsen

1 October 1886, letter by Else Jakobsen

3 January 1883, letter about Johannes Johnsen Telle [author of letter not yet identified]

3 July 1887, letter by Nikoline Benjaminsdatter

26 August 1889, letter by Maria Jakobsdatter Eide

10 August 1897, letter by Nikoline Benjaminsdatter

11 January 1883, letter by Grevel about Johannes Johnsen Telle

25 May 1893, letter by Mons Thorsen Hammer

15 September 1907, letter by Tore Knudsen Bugge

15 May 1911, letter by Peter E. Opland

\section{WORKS CITED}

Aaslestad, Petter. The Patient as Text: The Role of the Narrator in Psychiatric Notes, 1890-1990. Translated by Erik Skuggevik and Deborah Dawkin. Oxford: Radcliffe Publishing, 2009 [1997].

Andresen, Astri. “Patients for Life'. Pleiestiftelsen Leprosy Hospital 1850s-1920s.” Eds. Astri Andresen, Tore Grønlie, and Svein Atle Skålevåg. Hospitals, Patients and Medicine 18002000. Bergen: Stein Rokkan Centre for Social Sciences, 2004. 93-116.

Andresen, Astri. "Confinement and Care: Pleiestiftelsen No. 1.” Eds. Lorentz M. Irgens, Yngve Nedrebø, Sigurd Sandmo, and Arne Skivenes, in cooperation with the Leprosy Archives of Bergen. Leprosy. Førde: Selja, 2006. 71-79. 
Bamberg, Michael. "Stories: Big or Small: Why Do We Care?” Narrative Inquiry 16.1 (2006): $147-155$.

Bamberg, Michael and Alexandra Georgakopoulou. "Small Stories as a New Perspective in Narrative and Identity Analysis.” Text E् Talk 28 (2008): 377-396.

Bloch, Marc. The Historian's Craft. Translated by Peter Putnam. New York: Knopf, 1953.

Dinges, Martin and Vincent Barras, eds. Krankheit in Briefen im deutschen und französischen Sprachraum. 17.-21. Jahrhundert. Stuttgart: Franz Steiner, 2007.

Duden, Barbara. The Woman Beneath the Skin: A Doctor's Patients in Eighteenth-Century Germany. Translated by Thomas Dunlap. Cambridge, MA: Harvard University Press, 1991.

Ernst, Katharina. "Patientengeschichte: Die kulturhistorische Wende in der Medizinhistoriographie." Ed. Rolf Bröer. Eine Wissenschaft emanzipiert sich: Die Medizinhistoriographie von der Aufklärung bis zur Postmoderne. Pfaffenweiler: Centaurus, 1999. 97-108.

Ernst, Katharina. Krankheit und Heilung. Die medikale Kultur württembergischer Pietisten im 18. Jahrhundert. Stuttgart: Steiner, 2003.

Foucault, Michel. Madness and Civilization: A History of Insanity in the Age of Reason. Translated by Richard Howard. New York: Pantheon, 1965 [1961].

Genette, Gérard. Narrative Discourse: An Essay in Method. Translated by Jane E. Lewin. Ithaca, NY: Cornell University Press, 1980.

Genette, Gérard. Narrative Discourse Revisited. Translated by Jane E. Lewin. Ithaca, NY: Cornell University Press, 1988.

Genette, Gérard. "Fictional Narrative, Factual Narrative." Poetics Today 11.4 (1990): $755-774$.

Georgakopoulou, Alexandra. "Thinking Big with Small Stories in Narrative and Identity Analysis." Narrative Inquiry 16.1 (2006): 129-137.

Georgakopoulou, Alexandra. Small Stories, Interaction and Identities. Amsterdam: John Benjamins, 2007.

Georgakopoulou, Alexandra. "Small Stories Research: Methods—Analysis—Outreach." Eds. Anna De Fina and Alexandra Georgakopoulou. The Handbook of Narrative Analysis. Chichester: John Wiley \& Sons, 2015. 255-271.

Godøy, Bjørn Are. Ti tusen skygger. En historie om Norge og de spedalske. Oslo: Spartacus, 2014.

Goffman, Erving. Asylums: Essays on the Situation of Mental Patients and Other Inmates. New York: Anchor Books, 1961.

Gould, Tony. Don't Fence Me In: Leprosy in Modern Times. London: Bloomsbury, 2005.

Gussow, Zachary. Leprosy, Racism, and Public Health: Social Policy in Chronic Disease Control. Boulder, CO: Westview, 1989.

Hofer, Hans-Georg and Lutz Sauerteig. "Perspektiven einer Kulturgeschichte der Medizin." Medizinhistorisches Journal 42.2 (2007), Special issue: "Kulturgeschichte der Medizin": $105-141$.

Irgens, Lorentz M., Yngve Nedrebø, Sigurd Sandmo and Arne Skivenes, eds. Leprosy. Cooperation with the Leprosy Archives of Bergen. Førde: Selja, 2006.

Klein, Christian and Matías Martínez, eds. Wirklichkeitserzählungen: Felder, Formen und Funktionen nicht-literarischen Erzählens. Stuttgart: Metzler, 2009.

Koschorke, Albrecht. Wahrheit und Erfindung: Grundzüge einer Allgemeinen Erzähltheorie, 3rd ed. Frankfurt am Main: S. Fischer, 2013.

Kreiswirth, Martin. "Tell Me a Story: The Narrativist Turn in the Human Sciences." Eds. Martin Kreiswirth and Thomas Carmichael. Constructive Criticism: The Human Sciences in the Age of Theory. Toronto: University of Toronto Press, 1995. 61-87.

Kreiswirth, Martin. "Narrative Turn in the Humanities." Eds. David Herman, Manfred Jahn and Marie-Laure Ryan. Routledge Encyclopedia of Narrative Theory. London: Routledge, 2005. 377-382. 
Labov, William. "The Transformation of Experience in Narrative Syntax." Ed. William Labov. Language in the Inner City: Studies in the Black English Vernacular. Philadelphia: University of Philadelphia Press, 1972. 354-396.

Lachmund, Jens and Gunnar Stollberg. Patientenwelten: Krankheit und Medizin vom späten 18. bis zum frühen 20. Jahrhundert im Spiegel von Autobiographien. Opladen: Leske + Budrich, 1995.

Loetz, Francisca. Vom Kranken zum Patienten: "Medikalisierung" und medizinische Vergesellschaftung am Beispiel Badens 1750-1850. Stuttgart: Steiner, 1993.

Onarheim, Berit. "Jeg var spedalsk." Alle Kvinners Blad, 19 October 1957.

Osten, Philipp, ed. Patientendokumente: Krankheit in Selbstzeugnissen. Stuttgart: Steiner, 2010.

Palacio, Marie-France de, ed. L'écriture de la maladie dans les correspondances. Brest: CNRS, 2004.

Porter, Roy. "The Patient's View: Doing Medical History from Below." Theory and Society 14.2 (1985): 175-198.

Rieder, Philip. "Patients and Words: A Lay Medical Culture?" Eds. George S. Rousseau, Miranda Gill, David Haycock, and Malte Herwig. Framing and Imagining Disease in Cultural History. Hampshire: Palgrave Macmillan, 2003. 215-230.

Ritzmann, Iris. "Leidenserfahrung in der historischen Betrachtung: Ein Seiltanz zwischen sozialem Konstrukt und humanbiologischer Konstanz." Historische Zeitschrift. Supplements 31 (2001), "'Erfahrung' als Kategorie der Frühneuzeitgeschichte": 59-72.

Sandmo, Sigurd. "'Healing by the Cross': Discursive and Narrative Aspects of Leprosy in T. G. Rosaas' Korsets Lagedom (1910).” Eds. Astri Andresen and Tore Grønlie. Transferring Public Health, Medical Knowledge and Science in the 19th and 20th Century. Bergen: Stein Rokkan Centre for Social Sciences, 2007. 167-179.

Schiøtz, Aina. Folkets helse, landets styrke 1850-2003. Oslo: Universitetsforlag, 2003.

Schlich, Thomas. "Zeitgeschichte der Medizin: Herausgehensweisen und Probleme." Medizinhistorisches Journal 42.3/4 (2007): 269-298.

Stolberg, Michael. “'Mein äskulapisches Orakel!' Patientenbriefe als Quelle einer Kulturgeschichte der Krankheitserfahrung im 18. Jahrhundert." Österreichische Zeitschrift für Geschichtswissenschaften 7 (1996): 385-404.

Stolberg, Michael. "Der gesunde Leib: Zur Geschichtlichkeit frühneuzeitlicher Körpererfahrung." Historische Zeitschrift. Supplements, 31 (2001), "Erfahrung' als Kategorie der Frühneuzeitgeschichte": 37-57.

Stolberg, Michael. Homo Patiens: Krankheits- und Körpererfahrung in der Frühen Neuzeit. Cologne: Böhlau, 2003.

Vannes, Jorunn Nerby. "La meg være fri... En idehistorisk undersøkelse av 1800-tallets spedalskprosjekt og av spedalskes og 'de andres' erfaringer med spedalskhet på bakgrunn av ideologier og mentaliteter." Master's thesis, University of Oslo, 2008.

Vollset, Magnus. "Fra lidelse til trussel: Spedalskheten in Norge på 1800-tallet." Master’s thesis, University of Bergen, 2005.

Vollset, Magnus. "A Year at St. Jørgen-1885 Reflected in Documents." Eds. Lorentz M. Irgens, Yngve Nedrebø, Sigurd Sandmo, and Arne Skivenes, in cooperation with the Leprosy Archives of Bergen. Leprosy. Førde: Selja, 2006. 65-70.

Vollset, Magnus. "Globalizing Leprosy: A Transnational History of Production and Circulation of Medical Knowledge, 1850s-1930s." PhD diss., University of Bergen, 2013.

Wolff, Eberhard. "Perspektiven der Patientengeschichtsschreibung." Eds. Norbert Paul and Thomas Schlich. Medizingeschichte: Aufgaben, Probleme, Perspektiven. Frankfurt am Main: Campus, 1998. 311-334. 


\section{ABOUT THE AUTHOR}

Marie-Theres Federhofer is Professor of German Literature and Culture at the University of Troms $\varnothing$ - The Arctic University of Norway, and a member of the interdisciplinary research group "Health, Art and Society". She is currently working on the narrative techniques of patient documents, especially from the eighteenth and nineteenth century. She has published on Enlightenment patient narratives ("Der erzählende Patient. Krankheitsnarrative von Augenkranken in deutschen Aufklärungszeitschriften”, in Die Erzählung der Aufklärung, Beiträge zur DGEJ-Jahrestagung in Halle a. $d$. Saale, ed. F. Berndt and D. Fulda, Hamburg: Felix Meiner, 2018, 590-598) and on diaries written by female authors ("'So geht denn ein Schmerzenstag nach dem andern hin'. Krankheitserfahrungen in zwei Frauentagebüchern des 19. Jahrhunderts", DIEGESIS 6, no. 2, 2017: Krankheit erzählen/Narrating Illness). Webpage (only in Norwegian): https://uit.no/om/ enhet/ansatte/person?p_document_id=43437\&p_dimension_id=210121.

\section{NOTES}

1 I would, however, mention two edited collections that address the representation of illness in correspondence. The conference proceedings edited by literary scholar Marie-France de Palacio (Palacio 2004) are concerned with letters from the grands auteurs of the nineteenth and early twentieth century, with a special focus on the connection between illness and genius. The collection edited by historians of medicine Martin Dinges and Vincent Barras brings together papers in philosophy, literary studies and the history of medicine, the literary approaches concentrating on the seventeenth and eighteenth centuries and investigating, among other things, the representation of hypochondria and the correspondence between Diderot and Rousseau (Dinges and Barras 2007).

2 This applies in equal measure to documents from the more or less distant past (Loetz 1993, 57; Hofer and Sauerteig 2007, 124) and to more recent ones (Schlich 2007, 271272).

3 "Her Overlæge Löberg!/I dÿbeste Ærbødighet tager jeg mig herved den frihet at fremkomme med min bøn til Dem, nemlig at jeg av dem måtte oppdages påå Pleiestiftelsen 1 . Som grund hvorfor jeg forlod pleiestiftelsen var denne, at min Kone var sengeliggende $\mathrm{i}$ flere aar, og efterat jeg nu var reist bort, vilde eieren af Pladset jeg beboede drive hende paa bar mark uagtet jeg havde bygslet Pladset paa min og hendes Levetid. Da jeg erholdt Brev fra min Kone des angaaende, kunde jeg umuelig føre det over mitt hjerte, uden at see hjem til hende, og jeg var saaledes ligesom nødsaget til at forlade stiftelsen for at ordne hendes anliggende. Nu er imidlertid min kone død, og da jeg er saa ulykkelig at lide av en saadan sykdom der ikke giver haab om helbredelse, hvori mot jeg hellere paa den anden Side erfarer, at jeg bliver svagere dag for dag, saa har jeg her ingen at holde mig til, og jeg seer saaledes, uden deres Godgjørenhet mod mig, en mørk fremtid i møde. Jeg gjentager derfor min Bøn til dem og beder aller ydmygest om, at blive oppdaget på stiftelsen igen [...].” Knud Larsen Hjelmeland, 22 December 1871.

4 The other three institutions were the Lungegårdshospital (Bergen, opened 1849), Pleiestiftelsen Reknes (Molde, opened 1861) and Pleiestiftelsen Reitgjerdet (Trondheim, opened 1861). Pleiestiftelsen No. 1 opened in 1857. Reknes and Reitgjerdet were originally intended to be Pleiestiftelsen No. 2 and No. 3, but those names never took hold. As 
well as the four state institutions, patients with leprosy were also accepted by the St. Jørgen Hospital in Bergen, a private foundation dating from the Middle Ages. On the conflict between this private institution and its state counterparts, see Vollset (2006).

5 However, this impression may be slightly misleading, according to Andresen $(2004,2006)$ and Vollset $(2005,2006)$. Of the 295 applicants, only 234 actually arrived in Bergen, and by October the number of patients in the institution had fallen to 197 (Andresen 2006, 71). From a present-day viewpoint, Pleiestiftelsen No. 1 in Bergen appears to have been "a public leprosy institution where few persons with leprosy wanted to spend their lives" (Vollset 2006, 66).

6 A list of the letters (making no claim to completeness) can be found at the end of this paper. More detailed biographical information on some of the letter-writers is available at: http://gda.arkivverket.no/cgi-win/WebMeta.exe?slag=vismeny\&fylkenr=12\&knr=\&aa $\mathrm{r}=\&$ dagens $=\&$ katnr $=12$

7 Among the Norwegian leprosy patients whose names are still known today are Kari Nilsdatter Spidsøen and Harald Fjeldsbø. In 1879, the physician Gerhard Armauer Hansen, who had discovered the causative agent of leprosy in 1873, injected Spidsøen with the agent against her will in order to gather evidence for his theory of contagion. Armauer Hansen was taken to court in 1880 . Found guilty of causing bodily harm and abusing his office, he lost his position as a doctor at Pleiestiftelsen No. 1, although he was permitted to remain as chief medical officer. The court's finding is considered a breakthrough for the protection of patients' rights in Norway (but for a critical view of this interpretation, see Vollset 2005, 74-79). Harald Fjeldsbø was admitted to Pleiestiftelsen No. 1 in 1912, aged eighteen, and was one of the hospital's last patients. An interview with him was broadcast by Norwegian radio (NRK Hordaland) in 1957. See also Onarheim (1957).

8 Among the few exceptions are a master's thesis (Vannes 2008) and an essay by Vollset (2006). The studies by Andresen (2004, 2006) and Godøy (2014) do not specifically comment on documents written by leprosy patients themselves.

9 See the Leprosy Archives website, http://digitalarkivet.uib.no/lepra-eng/.

10 There is now a rich and detailed body of scholarship on leprosy research in Norway and the status of Norwegian leprosy research in a global context, contributed by scholars in social history, institutional history, and the history of science. These studies are beyond the scope of the present essay, so brief references must suffice: Gussow (1989); Schiøtz (2003); Andresen (2004, 2006); Gould (2005); Vollset (2005, 2006, 2013); Irgens et al. (2006); Sandmo (2007); Vannes (2008); Godøy (2014).

11 "min Sön Ole Monsen der lider av Spedalskhed i höi Grad". Mons Thorsen Hammer, 25 May 1893.

12 "Da jeg er en Mand i smaa Omstandigheder i Formues Forhold, er jeg ikke istand til at yde min syge Sön den fornödne Pleie og haaber den ansögde Hjælp tildeles mig." Mons Thorsen Hammer, 25 May 1893.

13 "i stor bedrövelse". Else Jakobsen, 1 October 1886.

14 "Han er nylig bleven saa ÿderst daarlig i oiene og hans ene haand svekes meget. Saa han [...] er intet i stand til at ernære seg noget selv. Han ser saa lidet at han kan ikke skrive selv til dem [...]”. Else Jakobsen, 1 October 1886.

15 "[...] tilader man seg dog at anbefale ham til paany at optages i Pleiestiftelsen, da hans Tilstand [...] skal have forværret sig, og hans Ophold i Hjemmets indskrænkende Lokale, hvor der findes flere Börn, burde befrygtes at have betenkelige Fölger baade for ham og desse." 11 January 1883.

16 "Jeg maa herved ærbödigst bede Dem, om De kunde foranstalte, at jeg fik Plads til at komme ind på Pleiestiftelsen for Spedalske i Bergen til Hösten. Jeg bliver nu saa svak, at man vanskelig kan forpleie mig ordentlig her hjemme, og saa har jeg tænkt paa at forsöge reise til Bergen, om jeg kunde faa Plads der." Maria Jakobsdatter Eide, 26 August 1889. 
17 "[...] kan det vel ikke gjøre så meget, om han får sit önske opfyldt." 15 September 1907.

18 "O hvor tungt det er for en Moder der om jeg saa tör sige maa bære sorgen allene og hvis kjærste tusende gange er blevet knusd." Else Jakobsen, 1 October 1886.

19 Zachary Gussow offers a positive evaluation of the various measures introduced in nineteenth-century Norway to combat leprosy, which he describes as a model to be followed by other Western nations: "The history of leprosy in Norway was a model of collaboration between research and public health practice. The model was both scientific and humane" (Gussow 1989, 84). Drawing particularly on Michel Foucault's Madness und Civilization (1961) and Erving Goffman's Asylums (1961), other studies in the history of science take a more critical attitude to the Norwegian campaign against leprosy, regarding it as a process by which the state and the medical profession assured their own control over the population. See Andresen (2004, 2006); Vollset (2006, 2013).

20 "Gunder Kristiansen Espeland [... ] har indfundet sig her hos mig og har erklæret sig villig at reise. Da det er mulight, at han kan senere hen ikke vilde være villig til at reise og da jeg i Henhold til Deres Opsats i Bergensposten av 29de d. A. maa ansee det som min [...] Pligt at arbeide til at de Spedalske kunne avsondres saa meget som muligt, saa haaber jeg at man paa grunn af Omstændighetene intet vil have [...] imod at jeg afsender ham nu [...].” Niels Anton Aall, 30 June 1876.

21 "The idea of minimal narrative presents a problem of definition that is not slight. [...] For me, as soon as there is an action or an event, even a single one, there is a story because there is a transformation, a transition from an earlier state to a later and resultant state" (Genette 1988, 18-19).

22 From the perspective of literary studies, we might find Georgakopoulou's accusations somewhat sweeping and perhaps intended rather as a way of legitimating her own small stories research. However, I will not address this further here.

23 "Min bestemmelse er og [sic] reise med rute 1 . Onsdags morgen den 23de i denne M. [...]." Nikoline Benjaminsdatter, 10 August 1897.

24 "Jeg tillader mig herved og spörge Forstanderen godhetdsfuldt om han vil vare saa snild og lad mig faa blive indlagt paa Værelset No 17 [...]." Nikoline Benjaminsdatter, 3 July 1897.

25 “[...] jeg seer [...] en mørk fremtid i møde." Knud Larsen Hjelmeland, 22 December 1871.

26 "[...] at jeg kunde faa forskafe mig de nödvendig ting som jeg maaet have med mig [...]." Johannes Mikelsen Kolstad, 29 February 1884.

27 Jølster is a municipality in western Norway. "Det har været mig umulig at skaffe ferdige overklæder til Ludvig og Johannes Gjesdal [...]. Jeg vil derfor bede Dem besørge dem klæder i Bergen paa Jölsters regning [...].” H. P. Hammer, 29 October 1913.

28 “[...] Du imodtages der borte nårsomhelst. Du får der alt gratis, det koster dig altså kun reisen [...]." Original emphasis. District physician Harald Lyche to Nils Endresen Svien, 1 July 1897.

29 "Patienten er to gange römt fra stiftelsen og hun optages nu kun under forutsetning av at dette ikke gjentager sig." Handwritten note on an application for admission to Pleiestiftelsen Reitgjerdet, 31 May 1919. 